\title{
A REVIEW: POTENSI RISIKO PADA SUPPLY CHAIN RISK MANAGEMENT
}

\author{
Dwi Iryaning Handayani \\ Jurusan Teknik Industri Fakultas Teknik \\ Universitas Panca Marga Probolinggo \\ Jalan Yos Sudarso 107 Pabean Dringu Probolinggo \\ dwiiryaninghandayani@yahoo.co.id
}

\begin{abstract}
Abstrak
Supply Chain Risk Management merupakan risiko yang terjadi pada aliran produk, informasi, bahan baku sampai pengiriman produk akhir yang mengancam keseluruhan supply chain dari pemasok awal hingga sampai konsumen. Sedangkan Supply chain disruptions (gangguan rantai pasok) adalah peristiwa tak terencana yang terjadi dalam rantai pasok yang bisa mempengaruhi aliran bahan dan komponen. Kejadian risiko yang terjadi didalam supply chain telah banyak dilakukan oleh beberapa peneliti sehingga perlu dilakukan review untuk mengetahui potensi risiko yang terjadi pada supply chain. Risiko yang terjadi pada supply chain berdasarkan hasil penelitian sebelumya terdapat 120 jenis risiko. Kesamaan risiko yang terjadi pada supply chain menghasilkan 17 jenis risiko yang sama pada supply chain dan terdapat 3 risiko yang sering terjadi yaitu risiko demand, keterlambatan bahan baku, Bencana alam (discruption), sedangkan 14 risiko lainnya yaitu, kwalitas supplier, kwalitas produk, sistem informasi, harga, suplai, produk rusak digudang, finansial, ketergantungan supplier, penundaan, kapasitas produksi, persediaan, kekurangan bahan baku, selisih stok dan politik. Adapun mitigasi yang dapat dilakukan dalam mengatasi gangguan supply chain ada 9 strategi yaitu: postponement, strategy stock, flexible supply base. make and buy, economic supply incentives, flexible transportation. revenue management via dynamic pricing and promotion, assortment planning. silent product rollover.
\end{abstract}

Kata Kunci: Potensi, Supply Chain, Risk Management

\section{PENDAHULUAN}

Studi tentang risiko dimulai pada abad ketujuh belas dengan menerapkan ilmu matematika teori probabilitas dalam perjudian (Frosdick, 1997). Risiko selalu dihubungkan dengan ketidakpastian bahwa probabilitas kenyataan tidak sesuai dengan harapan (Waters, 2007). Dimana risiko diartikan sebagai probabilitas kerugian dari suatu kejadian, sedangkan ketidakpastian dinyatakan sebagai exogenous disturbance. Begitu juga dengan Frosdick (1997) menyatakan bahwa risiko adalah probabilitas suatu kejadian yang mengakibatkan kerugian selama periode tertentu. Dimana risiko dapat memiliki makna positif jika berpeluang sebagai kesempatan dan bermakna negatif jika risiko berpeluang sebagai ancaman atau threat (Hilson, 2001). Namun risiko umumnya dipandang sebagai sesuatu yang negatif, seperti kehilangan, bahaya, dan konsekuensi lainnya sehingga risiko cenderung kepada kerugian yang terjadi dalam waktu tertentu (Frosdick, 1997). Kerugian merupakan wujud dari ketidakpastian yang seharusnya dipahami dan dikelola secara efektif oleh organisasi sebagai bagian dari strategi sehingga dapat menjadi nilai tambah dan mencapai tujuan organisasi.

Menurut Waters (2007) risiko pada sebuah industri dapat terjadi pada bagian supply chain atau mengancam keseluruhan supply chain dari pemasok awal hingga sampai konsumen. Faktor penyebab timbulnya risiko pada jaringan supply chain menurut Punniyamoorty (2013) antara lain jaringan supply chain yang semakin kompleks, tingginya ketergantungan kepada pemasok, adanya perbedaan interaksi organisasi didalam supply chain, pendeknya life cycle dari sebuah produk. Sedangkan menurut Skipper dan Hanna (2009) faktor penyebab dari timbulnya risiko yaitu adanya ketidakpastiaan dalam supply dan demand, siklus hidup dari produk dan teknologi semakin pendek, peningkatan penggunaan distribusi, manufaktur, dan mitra logistik. Sama halnya dengan Hadavale dan Alexander (2009) penyebab risiko pada supply chain di awali dengan ketidakpastiaan yang melekat dalam supply chain yag terdiri dari ketidakpastiaan permintaan, ketidakpastiaan 
kapasitas, ketidakpastiaan waktu pengiriman, perubahan teknologi, perubahan kondisi pasar, persaingan, isu politik, dan peraturan pemerintah. Biasanya, satu penyebab risiko dapat merangsang lebih dari satu kejadian risiko.

Kejadian risiko yang terjadi didalam supply chain menurut beberapa peneliti seperti, Zsidisin dkk (2004) risiko ketidakmampuan perusahaan dalam memenuhi permintaan pelanggan. Kekurangan material, biaya yang semakin meningkat, panjangnya lead time (Feng dan Mei, 2011). Sedangkan menurut Ritchie dan Brindley (2007) risiko yang sering terjadi pada supply chain antara lain: Risiko tertundanya pengiriman material akan menyebabkan berhentinya proses aktivitas produksi, risiko kenaikan biaya dari bahan baku, risiko kenaikan biaya juga dapat menyebabkan perpindahan tempat operasional dan mencari transportasi, risiko dari kerusakan salah satu mesin produksi di pabrik dapat menyebabkan terhentinya aktivitas produksi.

Berdasarkan hasil penelitian supply chain risk management telah menghasilkan risiko yang terjadi dalam supply chain, sehingga penulis mereview hasil penelitian yang berkaitan dengan risiko yang terjadi pada supply chain untuk mengetahui potensi risiko yang sering terjadi didalam supply chain dan rencana mitigasi yang harus dilakukan agar perusahaan mampu mengelola risiko secara efektif dalam menjamin kelancaran aliran produk sepanjang supply chain. (Jutner et al, 2003.)

\section{MANAJEMEN RISIKO RANTAI PASOK}

Supply Chain Risk Management (SCRM) merupakan perpaduan antara konsep Supply Chain Management dan Risk Management (Brindley, 2004), yang mana Supply Chain Risk Management berkolaborasi dengan patner supply chain dalam mengaplikasikan proses risk management. Berikut ini merupakan gambar supply chain risk management.

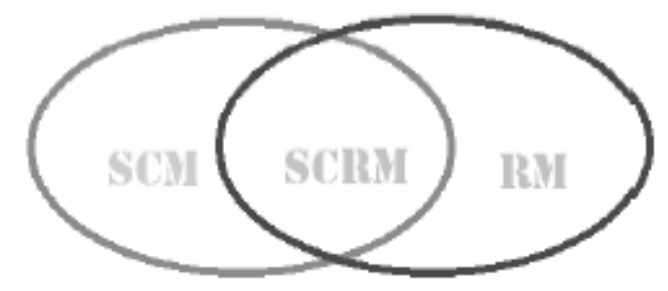

Gambar 1. Supply Chain Risk Management Sumber : (Brindley, 2004)

Menurut Zsidisin dkk (2004), Supply Chain Risk Management berkaitan dengan kegagalan pemasok dalam memasok barang sehingga permintaan konsumen tidak terpenuhi. Sedangkan Peck dkk (2003) Supply Chain Risk Management merupakan risiko yang terjadi pada aliran produk, informasi, bahan baku sampai pengiriman produk akhir. Risiko pada supply chain dapat didefinisikan sebagai suatu kejadian yang disebabkan oleh ketidak seimbangan antara permintaan dan pasokan. Sedangkan Supply chain disruptions (gangguan rantai pasok) adalah peristiwa tak terencana yang terjadi dalam rantai pasok yang bisa mempengaruhi aliran bahan dan komponen (Svensson, 2000). Gangguan rantai pasok dapat mengakibatkan berbagai masalah seperti panjangnya lead time, stock out, ketidak mampuan untuk memenuhi permintaan pelanggan, dan kenaikan biaya (Levy, 1995; Svensson, 2000; Riddalls dan Bennett, 2002; Chopra dan Sodhi, 2004).

Selain itu risiko merupakan fungsi dari tingkat ketidak pastian dan dampak dari suatu peristiwa (Sinha et al., 2004). Risiko menurut (Australian/New Zealand Standart (2004) merupakan suatu kemungkinan kejadian yang tidak diinginkan akan mempengarui tujuan. Risiko umumnya dipandang sebagai sesuatu yang negatif, seperti kehilangan, bahaya, dan konsekuensi lainnya. Risiko lebih dikaitkan dengan kerugian yang diakibatkan oleh kejadian yang mungkin terjadi dalam waktu tertentu (Jutner et al., 2003). Kerugian tersebut 
sebenarnya merupakan bentuk ketidak pastian yang seharusnya dipahami dan dikelola secara efektif oleh organisasi sebagai bagian dari strategi sehingga dapat menjadi nilai tambah dan mencapai tujuan organisasi. Menurut Goh et al. (2007) ada dua jenis risiko pada supply chain (SC) yaitu risiko yang timbul dari internal jaringan rantai pasok dan yang berasal dari lingkungan eksternal rantai pasok, yang mana risiko dapat dievaluasi mulai dari perencanaan, pengadaan, transportasi, gudang (Vanany et al., 2009). Perusahaan harus waspada dengan risiko yang dapat membahayakan keselamatan jangka pendek jangka panjang pada supply chain, disamping itu risiko dapat menggangu, menunda material, informasi dan arus kas, yang pada akhirnya dapat merusak penjualan, meningkatkan biaya, atau keduanya (Chopra dan Sodhi, 2004). Tang (2006) membagi risiko pada rantai pasok menjadi dua jenis risiko yaitu :

1. Risiko Operasional merupakan ketidakpastian yang berasal dari dalam rantai pasok yang terdiri dari ketidakpastian permintaan, supply dan biaya.

2. Risiko Gangguan (disruptions) merupakan risiko akibat gangguan dalam skala besar yang diakibatkan oleh alam dan manusia (seperti gempa bumi, banjir, badai, serangan teroris dan sebagainya) maupun krisis ekonomi (seperti devaluasi nilai tukar).

Risiko bisa datang dengan berbagai faktor penyebab dan bentuk, beragamnya risiko mendorong para peneliti untuk mengklasifikasikan risiko dalam rantai pasok. Risiko rantai pasok menurut Tumala dan Schoenher (2011) merupakan suatu peristiwa buruk yang dapat mempengaruhi operasi rantai pasok. Biasanya, satu penyebab risiko dapat merangsang lebih dari satu kejadian risiko. Misalnya, masalah dalam suatu sistem produksi pemasok dapat mengakibatkan kekurangan bahan dan menolak peningkatan yang terakhiri karena kurang mampu memasok (Pujawan et al., 2009). Terjadinya risiko dapat mengakibatkan kerugian yaitu sebuah konsekuensi negatif yang tidak diinginkan dan ketidak pastian. Oleh karena itu kemampuan untuk mengelola risiko secara efektif dianggap penting dalam menjamin kelancaran aliran produk sepanjang supply chain (Jutner et al., 2003).

\section{KATEGORI DAN JENIS RISIKO SUPPLY CHAIN MANAGEMENT}

Dalam menilai risiko yang terjadi, pertama kali kategori risiko harus ditentukan (Blackhurst, 2009). Chopra dan Sodhi (2004) mengelompokkan sembilan kategori risiko yaitu: gangguan, keterlambatan, sistem breakdown, peramalan, properti kekayaan intelektual, pengadaan, piutang, persediaan, dan kapasitas. Blackhurst (2009) merumuskan beberapa kategori risiko yaitu: kualitas, ketergantungan suplier, sistem informasi, manajemen dan kemanan. Tummala et al. (2011) mengkategorikan risiko menjadi sepuluh kategori antara lain: permintaan, penundaan, discruption, persediaan, manufacturing, kapasitas, suplai, sistem, sovereign, transportasi. Kategori risiko rantai pasok lainnya yaitu: Penundaan informasi, regulatory compliance, aksi dari pesaing, lingkungan politik, fluktuasi harga pasar, ketidakpastian biaya dan kualitas supplier (Olson dan Desheng, 2011). Tang (2006) yang mengatagorikan risiko rantai pasok kedalam operasi dan gangguan, yang mana risiko operasi meliputi permintaan, suplai dan biaya ketidak pastian. Sedangkan gangguan risiko meliputi: sunami, gempa, krisis ekonomi. Christoper dan Peck (2003) membagi risiko pada rantai pasok di bagi menjadi tiga bagian kategori risiko yaitu :

1) Risiko internal merupakan salah satu resiko dimana perusahaan suplier memiliki kontrol. meliputi risiko proses dan risiko kontrol.

a. Risiko proses merupakan risiko yang muncul dari kegiatan operasional dan manajerial akibat terganggunya suatu proses.

b. Risiko kontrol merupakan risiko yang timbul akibat kesalahan dalam menerapkan aturan yang ditetapkan perusahaan. Misal: besar order, kebijakan safety stock, transportasi.

2) Risiko eksternal perusahaan tetapi masih didalam jaringan supply chain, meliputi risiko permintaan dan risiko supply. 
a. Risiko permintaan merupakan risiko yang timbul akibat terganggunya aliran produk dan informasi yang secara khusus berhubungan dengan proses, kontrol, aset,dan intruktur pada downstream.

b. Risiko suplai merupakan risiko yang serupa timbul akibat terganggunya aliran produk dan informasi yang secara khusus berhubungan dengan proses, kontrol, dan instruktur pada upstream.

3) Risiko eksternal rantai pasok meliputi risiko lingkungan.

Risiko lingkungan dapat berpengaruh pada downstream maupun upstream proses. Risiko lingkungan dapat diakibatkan oleh bencana alam, faktor politik,dll.

Sedangkan dalam sebuah perusahaan, risiko dapat dikategorikan menjadi beberapa kategori, antara lain :

1) Operational risk adalah risiko-risiko yang berhubungan dengan operasional organisasi perusahaan.

2) Financial risk adalah risiko yang berdampak pada kinerja perusahaan.

3) Hazard risk adalah risiko kecelakaan fisik, seperti kejadian risiko sebagai akibat bencana alam, berbagai kejadian/kerusakan yang menimpa harta perusahaan, dan adanya ancaman pengerusakan.

4) Strategic risk mencakup kejadian risiko yang berhubungan dengan strategi perusahaan, politik ekonomi, peraturan dan perundangan, pasar bebas, risiko yang berkaitan dengan reputasi perusahaan, kepemimpinan, dan termasuk perubahan keinginan pelanggan. Adapun klasifikasi risiko rantai pasok menurut Cristoper dan Peck (2003) ditunjukkan pada Gambar 2

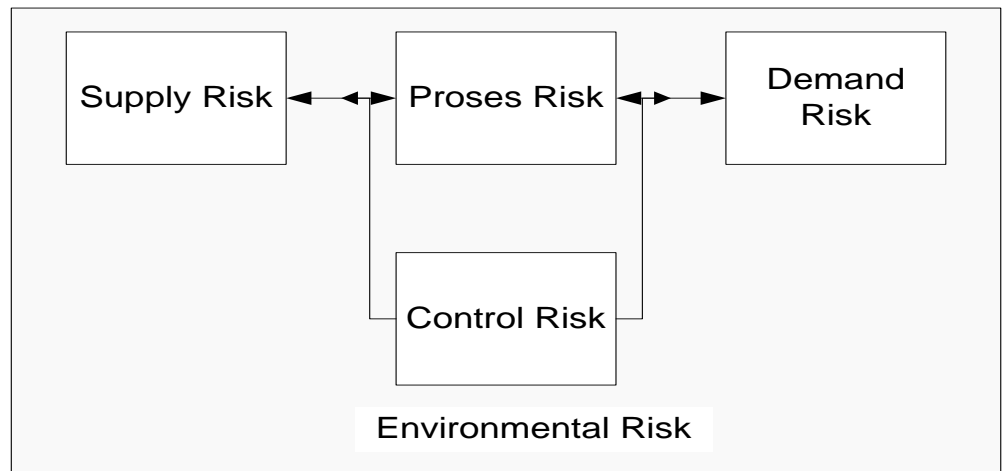

Gambar 2. Klasifikasi risiko pada rantai pasok (Cristoper dan Peck, 2003)

Tabel 1. Penelitian yang Mengidentifikasi Risiko Pada Supply Chain Management

\begin{tabular}{|c|c|c|}
\hline $\begin{array}{l}\text { Peneliti } \\
\text { (Tahun) }\end{array}$ & Area Penelitian & Jenis Risiko \\
\hline Handayani (2014) & $\begin{array}{l}\text { Risiko Rantai Pasok Minuman } \\
\text { Sari Apel dalam Perspektif } \\
\text { Sistem Traceability }\end{array}$ & $\begin{array}{l}\text { 1) Jumlah bahan baku dan produk yang ada digudang } \\
\text { tidak sesuai dengan yang ada di database perusahaan. } \\
\text { 2)Kekurangan barang dan bahan baku digudang. 3) } \\
\text { Keterlambatan penerimaan bahan baku. 4) Ketidak } \\
\text { sesuaian barang yang dipesan. 5) Material busuk. 6) } \\
\text { Sari buah rusak digudang. 7) Sari apel tercampur } \\
\text { dengan benda lainnya. 8) Kesalahan dalam } \\
\text { pengambilan galon sari buah yang tidak bersifat FIFO. } \\
\text { 9) Kualitas produk tidak sesuai. 10) Kesalahan } \\
\text { memberikan identitas. 11) Produk rusak digudang. 12) } \\
\text { Kesalahan pengangkutan produk. 13) produk cacat } \\
\text { dalam perjalanan. }\end{array}$ \\
\hline Indrawati (2013) & $\begin{array}{l}\text { Pemodelan Struktural } \\
\text { Keterkaitan Risiko Rantai } \\
\text { Pasok Dengan Pendekatan } \\
\text { Interpretive Structural } \\
\text { Modeling (Ism) }\end{array}$ & $\begin{array}{l}\text { 1) Gudang tidak cukup. 2) Keterlambatan/tidak sesuai } \\
\text { jadwal. 3) Stock out digudang penyangga. 4) } \\
\text { Pengiriman barang tidak aman } \\
\text { 5)Ketergantungan pada pemasok tunggal } \\
\text { 6) Barang digudang penyangga rusak/ susut }\end{array}$ \\
\hline
\end{tabular}




\begin{tabular}{|c|c|c|}
\hline & & $\begin{array}{l}\text { 7) Pembelian dari banyak sumber (multi sourcing). 9) } \\
\text { Pupuk hilang dijalan saat pengiriman ke gudang } \\
\text { penyangga 10) Gangguan Proses akibat bahan baku } \\
\text { KCl shortage. 11) Gangguan Proses akibat bahan baku } \\
\text { urea shortage 12) Gangguan Proses akibat bahan baku } \\
\text { phospate rock shortage. 13) Gangguan Proses akibat } \\
\text { bahan baku ZA shortage } \\
\text { 14) Selisih stok. 15) Penumpukan stok di gudang gresik } \\
\text { karena pergeseran musim tanam. 16) Kelambatan muat } \\
\text { keatas truk EMKL/kapal di gudang gresik. 17) } \\
\text { Pembelian dari banyak sumber (multi sourcing). 18) } \\
\text { Produktivitas menurun }\end{array}$ \\
\hline $\begin{array}{l}\text { Punniyamoorty } \\
(2013)\end{array}$ & $\begin{array}{l}\text { Assessment of supply chain } \\
\text { risk: scale development and } \\
\text { validation }\end{array}$ & $\begin{array}{l}\text { 1) Ketergantungan pemasok, 2) Jaringan supply chain } \\
\text { yang kompleks, 3) Perbedaan interaksi organisasi } \\
\text { didalam supply chain, 4) life cycle dari sebuah produk. }\end{array}$ \\
\hline Satria (2012) & $\begin{array}{l}\text { Pengelolahan Risiko Pada } \\
\text { Supply chain Di Graha Makmur } \\
\text { Cipta Pratama }\end{array}$ & $\begin{array}{l}\text { 1). Kesalahan evaluasi perencanaan dalam pencarian } \\
\text { dan pemilihan pemasok } \\
\text { 2) Alur informasi megenai permintaan customer ke } \\
\text { pemasok yang kurang tepat. 3) Kapasitas tambak dalam } \\
\text { pemenuhan udang segar yang dibutuhkan perusahaan } \\
\text { kurang memadai. 4) Persaingan dengan kompetitor } \\
\text { dalam mendapatkan udang segar. 5) Kurangnya } \\
\text { informasi mengenai pemasok yang memiliki potensi. } \\
\text { 6)Terjadinya bencana alam pada lokasi pemasok. 7) } \\
\text { Kurangnya skill dan pengalaman pegawai marketing. 8) } \\
\text { Kapasitas produksi yang kurang memadai. 9) Kurang } \\
\text { kapabilitasnya mesin yang dimiliki logistic provider. } \\
\text { 10) Kesalahan dalam memilih logistic provider. 11) } \\
\text { Strategi marketing yang kurang tepat. 12) Kurang } \\
\text { adanya prioritas CRM dalam perusahaan. 13) Tidak } \\
\text { adanya customer tetap. 14) Ketidak pastian dari kondisi } \\
\text { customer berkaitan dengan lokasi/prekonomian negara. } \\
\text { 15)Tidak adanya informasi demand dan forcasting } \\
\text { demand maupun supply }\end{array}$ \\
\hline $\begin{array}{l}\text { Feng dan Mei } \\
\text { (2011) }\end{array}$ & $\begin{array}{l}\text { Disruption risks in the Supply } \\
\text { Chain }\end{array}$ & $\begin{array}{l}\text { 1) Tidak dapat memenuhi permintaan, 2) kekurangan } \\
\text { bahan baku, 3) Biaya yang semakin meningkat, 4) } \\
\text { panjangnya lead time }\end{array}$ \\
\hline $\begin{array}{l}\text { Tummala et al. } \\
\text { (2011) }\end{array}$ & $\begin{array}{l}\text { Assessing and managing risks } \\
\text { using the } \\
\text { Supply Chain Risk Management } \\
\text { Process (SCRMP), }\end{array}$ & $\begin{array}{l}\text { 1) Permintaan. 2) Penundaan. 3) Discruption, 4) } \\
\text { Persediaan. 5) Manufacturing. 6) Kapasitas. 7) Suplai. } \\
\text { 8) Sistem. 9) sovereign. 10) transportasi. }\end{array}$ \\
\hline $\begin{array}{l}\text { (Olson dan } \\
\text { Desheng, 2011). }\end{array}$ & $\begin{array}{l}\text { Risk management models for } \\
\text { supply chain: a } \\
\text { scenario analysis of } \\
\text { outsourcing to China, }\end{array}$ & $\begin{array}{l}\text { 1) Penundaan informasi,. 2) regulatory compliance. 3) } \\
\text { aksi dari pesaing, 4) lingkungan politik. 5) fluktuasi } \\
\text { harga pasar. 6) ketidakpastian biaya, 7) kualitas } \\
\text { supplier }\end{array}$ \\
\hline $\begin{array}{l}\text { Skipper dan Hanna } \\
\text { (2009) }\end{array}$ & $\begin{array}{l}\text { Minimizing supply chain } \\
\text { disruption risk through } \\
\text { enhanced flexibility }\end{array}$ & $\begin{array}{l}\text { 1) Ketidak pastian supply dan demand, 2) life cycle } \\
\text { dari sebuah produk, 3) Teknologi semakin pendek, 4) } \\
\text { Peningkatan penggunaan distribusi, 5) manufaktur, 6) } \\
\text { mitra logistik }\end{array}$ \\
\hline $\begin{array}{l}\text { Hadavale dan } \\
\text { Alexander (2009) }\end{array}$ & Supply chain risk management & $\begin{array}{l}\text { 1) Ketidak pastian permintaan, 2) ketidak pastian } \\
\text { kapasitas, 3) ketidak pastian pengiriman, 4) Perubahan } \\
\text { teknologi, perubahan kondisi pasar, 5) Persaingan, 6) } \\
\text { Isu politik, 7) Peraturan pemerintah }\end{array}$ \\
\hline (Neiger, 2009) & $\begin{array}{l}\text { Supply chain risk identification } \\
\text { with value focused process } \\
\text { engineering }\end{array}$ & $\begin{array}{l}\text { 1) Suplier tidak mampu memenuhi kebutuhan yang } \\
\text { sesuai spesifikasi. 2) ketidakstabilan finansial suplier. } \\
\text { 3) ketidakstandaran cara komunikasi dengan suplier. 4) } \\
\text { ketergantungan pada suplier. }\end{array}$ \\
\hline Blackhurst (2009) & $\begin{array}{l}\text { Supplier risk assessment and } \\
\text { monitoring for the automotive } \\
\text { industry, }\end{array}$ & $\begin{array}{l}\text { 1) Kualitas. 2) Ketergantungan suplier. 3) Sistem } \\
\text { informasi. 4) Manajemen dan kemanan. }\end{array}$ \\
\hline $\begin{array}{l}\text { Ritchie dan } \\
\text { Brindley (2007) }\end{array}$ & $\begin{array}{l}\text { An emergent framework for } \\
\text { supply chain risk management } \\
\text { and performance measurement }\end{array}$ & $\begin{array}{l}\text { 1) Tertundanya pengiriman material, 2) terhentinya } \\
\text { aktivitas produksi, 3) risiko kenaikan biaya, 4) } \\
\text { kerusakan mesin produksi }\end{array}$ \\
\hline Tang (2006a) & Perspectives in supply chain & 1) Permintaan. 2) Suplai dan 3) Biaya ketidak pastian. \\
\hline
\end{tabular}




\begin{tabular}{|l|l|l|}
\hline & risk management & 4) Sunami. 5) Gempa. 6) Krisis ekonomi. \\
\hline (Zsidisin, 2005) & $\begin{array}{l}\text { Supply chain risk management } \\
\text { developments, issues and } \\
\text { challenges }\end{array}$ & $\begin{array}{l}\text { 1) Kualitas bahan baku rendah yang mengakibatkan } \\
\text { downtime. 2) Dinamika harga. 3) kualitas barang dan } \\
\text { jasa yang rendah. }\end{array}$ \\
\hline $\begin{array}{l}\text { Chopra dan Sodhi } \\
(2004)\end{array}$ & $\begin{array}{l}\text { Managing risk to avoid supply- } \\
\text { chain breakdown }\end{array}$ & $\begin{array}{l}\text { 1) Gangguan, 2) Keterlambatan, 3) Sistem breakdown. } \\
\text { 4) Peramalan. 5) Properti kekayaan intelektual. 6) } \\
\text { Pengadaan. 7) Piutang. 8) Persediaan dan 9) Kapasitas. }\end{array}$ \\
\hline Hallikas dkk., 2004 & $\begin{array}{l}\text { Risk management processes in } \\
\text { suplier networks }\end{array}$ & $\begin{array}{l}\text { 1) Ketidak sesuaian permintaan. 2) Pemenuhan } \\
\text { pengiriman ke konsumen. 3) Pengelolaan biaya. 4) } \\
\text { harga. 5) fleksibilitas. 6) Kelemahan pada sumber } \\
\text { daya. }\end{array}$ \\
\hline
\end{tabular}

Tabel 1 menunjukkan hasil penelitian supply chain risk management yang tergolong menjadi empat katagori yaitu: operational risk, financial risk, hazard risk. strategic risk. Risiko yang terjadi di supply chain dapat bersumber dari beberapa hal sebagai berikut; tingkah laku manusia, isu teknologi, bahaya kesehatan dan keamanan, legal, kebijakan, peralatan dan perlengkapan, lingkungan, keuangan/pasar, kejadian alam. Risiko yang terjadi pada supply chain berdasarkan hasil penelitian sebelumya terdapat 120 jenis risiko, dari ke 120 jenis risiko supply chain terdapat kesamaan jenis risiko yang terjadi pada masing-masing hasil penelitian sebelumnya.

Kesamaan risiko yang terjadi pada supply chain berdasarkan penelitian sebelumnya yang dilakukan pada industri manufaktur menghasilkan 17 jenis risiko yang sama pada supply chain dan terdapat 3 risiko yang sering terjadi yaitu risiko demand, keterlambatan bahan baku, Bencana alam (discruption), sedangkan 14 risiko lainnya yaitu , kwalitas supplier, kwalitas produk, sistem informasi, harga, suplai, produk rusak digudang, finansial, ketergantungan supplier, penundaan, kapasitas produksi, persediaan, kekurangan bahan baku, selisih stok dan politik.

\section{MITIGASI RISIKO}

Mitigasi risiko merupakan proses pencegahan dalam penanganan risiko dalam menentukan perlakuan yang tepat untuk mengatasi risiko yang terjadi. Masing-masing risiko memiliki perlakuan yang berbeda, 5 jenis perlakuan terhadap risiko, yaitu :

a) menghindari risiko (avoid), b) memindahkan risiko (transfer), c) mengurangi peluang atau dampak yang terjadi (mitigate), d) menerima risiko (accept). Perlakuan risiko menurut Australian New Zealand Standards (AS/NZS 4360:2004) adalah dengan memperhatikan aspek likelihood dan consequences yang ditimbulkan oleh risiko tersebut, seperti yang dijelaskan pada Tabel 3.

Tabel 3 Risk Treatment

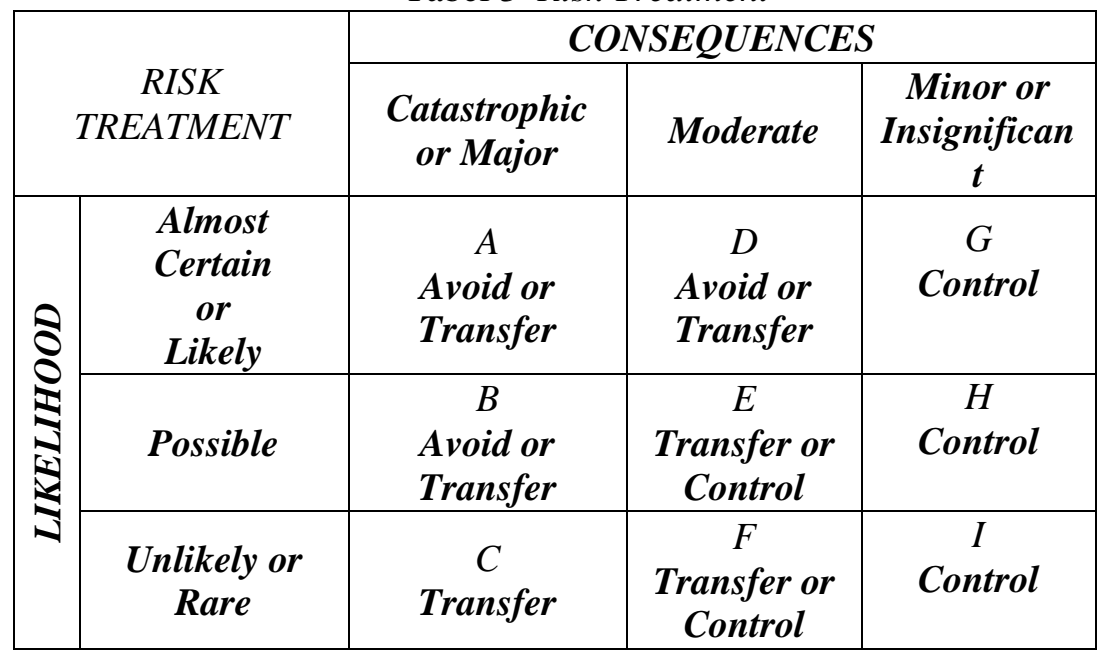

(Sumber: AS/NZS 4360:2004) 


\section{STRATEGI MITIGASI PADA SUPPLY CHAIN}

Pada Supply Chain, risiko dapat terjadi dengan berbagai faktor penyebab sehingga Tang (2005) mengembangkan strategi mitigasi yang meliputi supply management, demand management, product management, dan information management. Masing-masing pendekatan dasar tersebut bertujuan untuk memperbaiki operasi pada supply chain dengan koordinasi dan kolaborasi sebagai berikut :

1. Perusahaan berkoordinasi atau berkolaborasi pada upstream partner untuk memastikan efisiensi pada pasokan material di sepanjang supply chain

2. Perusahaan dapat berkoordinasi dan berkolaborasi dengan downstream partner untuk mempengaruhi permintaan dengan cara yang menguntungkan

3. Perusahaan dapat memodifikasi produk maupun proses sehingga memudahkan supply dalam memenuhi permintaan.

4. Perusahaan dapat memperbaiki kolaborasi dan koordinasinya jika dapat mengakses berbagai tipe informasi yang tersedia pada partner supply chain

Selain itu Tang (2006) menjelaskan 9 strategi untuk mengatasi gangguan pada supply chain:

1. Postponement, merupakan startegi untuk menyeragamkan produk maupun process design seperti standardization, commonality, modular design dan operations reversal, untuk menunda diferensiasi produk.

2. Strategy Stock, Dalam menyimpan safety stock, perusahaan sebaiknya menyimpan persediaan pada " strategic locations (warehouse, logistic hubs, distributions centres) dimana lokasi penyimpanan tersebut dapat dibagi penggunaannya dengan supply chain partner

3. Flexible supply base. Untuk menjamin kelancaran pasokan ketika terjadi gangguan, maka diperlukan adanya pasokan yang fleksibel sehingga dapat mudah berganti antara satu pemasok yang satu dengan yang lain.

4. Make and Buy. Suatu supply chain akan lebih tangguh jika beberapa barang diproduksi secara in-house dan beberapa produk yang lain di outsourcing ke supplier.

5. Economic supply incentives. Memberi insentif ekonomi untuk menanggung risiko financial secara bersama-sama dan membeli stok yang tidak terjual dengan harga rendah

6. Flexible transportation. Kelancaran aktivitas pada supply chain sangat dipengaruhi oleh fleksibelitas pada transportasi dapat dilakukan dengan tiga hal 1) Multi-modal transportation, 2) Multi carrier transportation, 3) Multiple routes

7. Revenue management via dynamic pricing and promotion. Strategi ini sangat cocok untuk barang yang mudah rusak. Perubahan harga dan promosi dapat mempengaruhi permintaan pada konsumen

8. Assortment planning. Merubah penampilan produk dan penempatannya di rak-rak retailer untuk mempengaruhi minat dan permintaan pada konsumen.

9. Silent product rollover. Meluncurkan produk baru secara diam-diam tanpa memberikan pengumuman secara formal. 


\section{KESIMPULAN}

Risiko yang terjadi pada supply chain berdasarkan hasil penelitian sebelumya terdapat 120 jenis risiko, dari ke 120 jenis risiko supply chain terdapat kesamaan jenis risiko yang terjadi pada masing-masing hasil penelitian sebelumnya. Kesamaan risiko yang terjadi pada supply chain berdasarkan penelitian sebelumnya yang dilakukan pada industri manufaktur menghasilkan 17 jenis risiko yang sama pada supply chain dan terdapat 3 risiko yang sering terjadi yaitu risiko demand, keterlambatan bahan baku, Bencana alam (discruption), sedangkan 14 risiko lainnya yaitu, kwalitas supplier, kwalitas produk, sistem informasi, harga, suplai, produk rusak digudang, finansial, ketergantungan supplier, penundaan, kapasitas produksi, persediaan, kekurangan bahan baku, selisih stok dan politik. Adapun mitigasi yang dapat dilakukan dalam mengatasi gangguan supply chain ada 9 strategi yaitu: Postponement, Strategy Stock, Flexible supply base. Make and Buy. Economic supply incentives. Flexible transportation. Revenue management via dynamic pricing and promotion. Assortment planning. Silent product rollover. 
Tabel 2. Potensi Risiko Pada Supply Chain Management

\begin{tabular}{|c|c|c|c|c|c|c|c|c|c|c|c|c|c|c|c|c|c|}
\hline \multirow[b]{2}{*}{$\begin{array}{c}\text { Risiko Yang } \\
\text { Terjadi }\end{array}$} & \multicolumn{16}{|c|}{ Peneliti Sebelumnya } & \multirow{2}{*}{$\begin{array}{l}\text { Jum lah } \\
\text { Peneliti }\end{array}$} \\
\hline & $\begin{array}{r}\text { Hallikas } \\
(2004)\end{array}$ & $\begin{array}{c}\text { Chopra } \\
\text { \& } \\
\text { Sodhi } \\
(2004)\end{array}$ & $\begin{array}{c}\text { Zsidisin } \\
(2005)\end{array}$ & $\begin{array}{l}\text { Tang } \\
(2006)\end{array}$ & $\begin{array}{c}\text { Rit chie } \\
\& \\
\text { Brindley } \\
(2007)\end{array}$ & $\begin{array}{l}\text { Neiger } \\
(2009)\end{array}$ & $\begin{array}{c}\text { Black } \\
\text { hurst } \\
(2009)\end{array}$ & $\begin{array}{c}\text { Hada } \\
\text { vale \& } \\
\text { Alexan } \\
\text { der } \\
(2009)\end{array}$ & $\begin{array}{l}\text { Skipper } \\
\text { dan } \\
\text { Hanna } \\
(2009)\end{array}$ & $\begin{array}{c}\text { Tum } \\
\text { mala } \\
(2011)\end{array}$ & $\begin{array}{c}\text { Olson } \\
\text { dan } \\
\text { Desheng } \\
(2011) .\end{array}$ & $\begin{array}{c}\text { Feng } \\
\text { dan } \\
\text { Mei } \\
(2011)\end{array}$ & $\begin{array}{c}\text { Yogi } \\
\text { Andi } \\
\text { Satria } \\
(2012)\end{array}$ & $\begin{array}{c}\text { Dian } \\
\text { (2013) }\end{array}$ & $\begin{array}{c}\text { Punniya } \\
\text { moorty } \\
(2013)\end{array}$ & $\begin{array}{c}\text { Han } \\
\text { dayani } \\
(2014)\end{array}$ & \\
\hline Demand & $\sqrt{ }$ & & & $\sqrt{ }$ & & & & $\sqrt{ }$ & $\sqrt{ }$ & $\sqrt{ }$ & & $\sqrt{ }$ & $\sqrt{ }$ & & & & 7 \\
\hline $\begin{array}{c}\text { Keterlamba } \\
\text { Tan bahan } \\
\text { baku }\end{array}$ & & $\sqrt{ }$ & & & $\sqrt{ }$ & & & & & & & & & $\sqrt{ }$ & & $\sqrt{ }$ & 4 \\
\hline $\begin{array}{c}\text { Bencana alam } \\
\text { (discruption) }\end{array}$ & & $\sqrt{ }$ & & $\sqrt{ }$ & & & & & & $\sqrt{ }$ & & & $\sqrt{ }$ & & & & 4 \\
\hline $\begin{array}{l}\text { Kwalitas } \\
\text { Suplier }\end{array}$ & & & & & & & $\sqrt{ }$ & & & & $\sqrt{ }$ & & & & & $\sqrt{ }$ & 3 \\
\hline $\begin{array}{c}\text { Kwalitas } \\
\text { produk }\end{array}$ & & & $\sqrt{ }$ & & & & $\sqrt{ }$ & & & & & & & & & $\sqrt{ }$ & 3 \\
\hline $\begin{array}{c}\text { Kekurangan } \\
\text { bahan baku }\end{array}$ & & & $\sqrt{ }$ & & & & & & & & & $\sqrt{ }$ & & & & $\sqrt{ }$ & 3 \\
\hline $\begin{array}{l}\text { Kapasitas } \\
\text { Produksi }\end{array}$ & & $\sqrt{ }$ & & & & & & $\sqrt{ }$ & & & & & $\sqrt{ }$ & & & & 3 \\
\hline $\begin{array}{l}\text { Ketergantunga } \\
\text { n Suplier }\end{array}$ & & & & & & $\sqrt{ }$ & $\sqrt{ }$ & & & & & & & & $\sqrt{ }$ & & 3 \\
\hline Financial & $\sqrt{ }$ & & & & & & & & & & $\sqrt{ }$ & $\sqrt{ }$ & & & & & 3 \\
\hline $\begin{array}{c}\text { Sistem } \\
\text { informasi }\end{array}$ & & & & & & & $\sqrt{ }$ & & & & & & $\sqrt{ }$ & & & $\sqrt{ }$ & 3 \\
\hline Suplai & & & & $\sqrt{ }$ & & & & & $\sqrt{ }$ & $\sqrt{ }$ & & & & & & & 3 \\
\hline Persaingan & & & & & & & & $\sqrt{ }$ & & & $\sqrt{ }$ & & $\sqrt{ }$ & & & & 3 \\
\hline $\begin{array}{l}\text { Selisih stock } \\
\end{array}$ & & & & & & & & & & & & & & $\sqrt{ }$ & & $\sqrt{ }$ & 2 \\
\hline Persediaan & & $\sqrt{ }$ & & & & & & & & $\sqrt{ }$ & & & & & & & 2 \\
\hline Penundaan & & & & & & & & & & $\sqrt{ }$ & $\sqrt{ }$ & & & & & & 2 \\
\hline $\begin{array}{c}\text { Produk rusak } \\
\text { digudang }\end{array}$ & & & & & & & & & & & & & & $\sqrt{ }$ & & $\sqrt{ }$ & 2 \\
\hline Harga & $\sqrt{ }$ & & $\sqrt{ }$ & & & & & & & & & & & & & & 2 \\
\hline Politik & & & & & & & & $\sqrt{ }$ & & & $\sqrt{ }$ & & & & & & 2 \\
\hline
\end{tabular}




\section{DAFTAR PUSTAKA}

[1] Blackhurst, J., Craighead., Kevin P. Scheibe and Danny J. Johnson (2008), Supplier risk assessment and monitoring for the automotive industry, Physical Distribution \& Logistics Management Vol. 38 No. 2, 2008, pp. 143-165

[2] Brindly Claire (2004), Supply Chain Risk, Hampshire Ashgate

[3] Christopher, M., \& Peck, H. (2003), Building the resilient supply chain. Cranfield School of Management.

[4] Council of Standards Australia and Council of Standards New Zaeland 2006, Risk Management Standard AS/NZS4360: 2004.

[5] Chopra, S., Sodhi, M.S. (2004), Managing Risk To Avoid Supply-Chain Breakdown, MIT Sloan Management Review, pp. 53-61

[6] Frosdick, M. (1997), "The techniques of risk management are insufficient in themselves", Disaster Prevention and Management, Vol. 6 No. 3, pp. 165-77.

[7] Feng, L. I., dan Mei, L. I. (2011), Disruption risks in the Supply Chain, IEEE

[8] Goh, M., Lim, J.Y.S. and Meng, F. (2007), A stochastic model for risk management in global supply chain networks, uropean Journal of Operational Research, Vol. 182, pp. 164-73.

[9] Hallikas, J., Karvonen, I., Pulkkinen, U., Virolainen, V.-M. and Tuominen, M. (2004), Risk management processes in supplier networks, International Journal of Production Economics, Vol. 90, pp. 47-58.

[10] Hillson, D 2001, Extending the Risk Process to Manage Opportunitie, Proceeding of the Fourth European Project Management Conference, 6-7 June, London.

[11] Hadavale, R. S., dan Alexander, S. M. (2009), Supply chain risk management, Proceedings of the industrial engineering research conference, hal. 1363-1369.

[12] Handayani, Dwi Iryaning, (2014) Risiko Rantai Pasok Minuman Sari Apel dalam Perspektif Sistem Traceability, Jurnal JATI Undip Volume 9 No 1 Januari 2014, ISSN 19071434

[13] Indrawati, Dian Catharina. (2013), Pemodelan Struktural Keterkaitan Risiko Rantai Pasok serta Pembobotannya dengan Pendekatan Interpretive Structural Modeling (ISM) dan Analytical Network Process (ANP). Laporan Thesis, Jurusan Teknik Industri ITS

[14] Juttner, U., Peck, H., \& Christopher, M. (2003). Supply chain risk management: Outlining an Agenda for future research. International Journal of Logistics: Research and Applications, 6(4), 197-210.

[15] Levy, D. (1995), International sourcing and supply chain stability, Journal of International Business Studies, Vol. 26 No. 2, pp. 343-60. Mayer, R.J., Painter, M.K. and de Witte, P.S. (199

[16] Neiger, D., Rotaru, K., Churilov, L. (2009), Supply chain risk identification with value-focused process engineering, Journal of Operations Management, Vol. 27, pp. 154-68.

[17] Olson David L., Desheng Wu (2011), Risk management models for supply chain:a scenario analysis of outsourcing to China, Supply Chain Management: An International Journal 16/6, 401-408

[18] Peck, H., Christopher, M. dan Kingdom, U. (2003), "Supply chain risk management : Outlining an agenda for future research", International Journal of Logistics : Research \& Applications, Vol.6 No.4, hal.197-210.

[19] Punniyamoorthy, M. (2013), "Assessment of supply chain risk: scale development and validation", Benchmarking: An International Journal, Vol.20 No.1, hal.79-105.

[20] Pujawan, I. N., dan Geraldin, L. H. (2009), "House of risk: a model for proactive supply chain risk management", Business Process Management Journal, Vol.15 No.6, hal. 953-967. 
[21] Ritchie, B., dan Brindley, C. (2007), "An emergent framework for supply chain risk management and performance measurement",Journal of the Operational Research Society, Vol.58 No.11, hal. 1398-1411.

[22] Riddalls, C. and Bennett, S. (2002), Production-inventory system controller design and supply chain dynamics, International Journal of Systems Science, Vol. 33 No. 3, pp. 181-95.

[23] Satria Adi Y., (2012) Pengelolahan risiko ada supply chain PT Graha Makmur Cipta Pratama, Laporan Tugas Akhir Jurusan Teknik Industri ITS.

[24] Skipper, J. B., dan Hanna, J. B. (2009), "Minimizing supply chain disruption risk through enhanced flexibility", International Journal of Physical Distribution \& Logistics Management, Vol.39 No.5, hal. 404-427.

[25] Svensson, G. (2000), A conceptual framework for the analysis of vulnerability in supply chains, International Journal of Physical Distribution \& Logistics Management, Vol. 30 No. 9, pp. 731-49.

[26] Sinha, P.R., Whitman, L.E. and Malzahn, D. (2004), Methodology to mitigate supplier risk in an aerospace supply chain, Supply Chain Management: An International Journal, Vol. 9 No. 2, pp. 154-68.

[27] Tang, C.S. (2006), Perspectives in supply chain risk management, International Journal of Production Economics, Vol. 103, pp. 451-488.

[28] Tang, C. S. 2005. Perspective in Supply Chain Risk Management: A Review, Los Angeles.

[29] Tummala Rao, Schoenherr Tobias (2011), Assessing and managing risks using the Supply Chain Risk Management Process (SCRMP), Supply Chain Management: An International Journal, 474-483

[30] Tang, C. S. (2006), "Perspectives in supply chain risk management", International Journal of Production Economics, Vol. 103 No. 2, hal. 451-488.

[31] Tang, C.S. (2006), Perspectives in supply chain risk management, International Journal of Production Economics, Vol. 103, pp. 451-488.

[32] Tang, C. S. 2005. Perspective in Supply Chain Risk Management: A Review, Los Angeles.

[33] Vanany, I., S. Zaelani, and Pujawan, N., (2009), Supply chain risk management: literature review and future research. International Journal of Information Systems and Supply Chain Management, Vol.2, no.1, pp.16-33.

[34] Waters, D. (2007), Supply Chain Risk Management: Vulnerability and Resilience in Logistics, Kogan Page, London and Philadeplhia.

[35] Zsidisin, G.A., Ritchie, B. (2009), Supply chain risk management - developments, issues and challenges, International Series in Operations Research \& Management Science, Vol. 124, pp. 1-12.

[36] 2004. Tutorial: Risk Management Standard, AS/NZS 4360: 2004, Broadleaf Capital International Pty Ltd. 